\title{
O007: Lesser and lesser - the impact of small volumes in hand disinfection on quality of hand coverage and antimicrobial efficacy
}

\author{
G Kampf ${ }^{1,2^{*}}$, S Ruselack ${ }^{3}$, S Eggerstedt ${ }^{3}$, N Nowak $^{4}$, M Bashir $^{5}$ \\ From 2nd International Conference on Prevention and Infection Control (ICPIC 2013) \\ Geneva, Switzerland. 25-28 June 2013
}

\section{Introduction}

With some alcohol-based hand rubs a volume of $1.1 \mathrm{~mL}$ is recommended per application but it is unknown if such a small volume is sufficient to cover both hands and if it fulfills current efficacy standards.

\section{Objectives}

Aim of our study was to determine hand coverage of three hand rubs (one gel based on $70 \%$ ethanol, one gel based on $85 \%$ ethanol, one foam based on $70 \%$ ethanol) applied with various volumes (all products: $1.1 \mathrm{~mL}, 2$ $\mathrm{mL}, 2.4 \mathrm{~mL}, 1$ push and 2 pushes; only foam product: $1.1 \mathrm{~mL}$ foam, $2 \mathrm{~mL}$ foam, $2.4 \mathrm{~mL}$ foam).

\section{Methods}

Fifteen subjects applied each product, supplemented with a fluorescent dye with each volume. Quality of coverage was determined under UV light. The efficacy of the three hand rubs was determined according to ASTM E 1174-06 and ASTM E 2755-10. The hands of 12 subjects per experiment were artificially contaminated with Serratia marcescens and the products applied as recommended $(1.1 \mathrm{~mL}$ for the products based on $70 \% \mathrm{v} / \mathrm{v}$ ethanol; $2 \mathrm{~mL}$ for the product based on $85 \% \mathrm{w} /$ $\mathrm{w}$ ethanol). The $\log _{10}$-reduction was calculated per product.

\section{Results}

A volume $<2 \mathrm{~mL}$ yielded a high rate of incomplete coverage $(76 \%-87 \%)$, a volume $\geq 2 \mathrm{~mL}$ revealed better

'Bode Science Center, Bode Chemie GmbH, Hamburg, Germany

Full list of author information is available at the end of the article results $(18 \%-40 \%)$. There was a significant difference between the five volumes used with all hand rubs ( $\mathrm{p}<$ 0.001 ; analysis of variance) but not between the three hand rubs themselves $(\mathrm{p}=0.442)$. Application of $1.1 \mathrm{~mL}$ of the hand rubs based on $70 \%$ ethanol yielded a $\log _{10^{-}}$ reduction of 1.85 or $1.60 \log _{10}$ (ASTM E 1174-06) and failed the US FDA efficacy requirement. Application of $2 \mathrm{~mL}$ of the hand rub based on $85 \%$ ethanol reduced the contamination by $2.06 \log _{10}$ (ASTM E 1174-06) and fulfilled the US FDA efficacy requirement. Similar results were obtained according to ASTM E 2755-10.

\section{Conclusion}

Our data indicate that hand rubs based on $70 \%$ ethanol and recommended with a volume of $1.1 \mathrm{~mL}$ per application are not suitable to ensure complete coverage of both hands and do not fulfill the current ASTM efficacy standard requirements. Infection control practitioners should try to ensure patient safety by not reducing the volume of hand rub required for adequate for hand disinfection.

\section{Disclosure of interest}

G. Kampf Employee of Bode Chemie GmbH, Hamburg, Germany, S. Ruselack Employee of Bode Chemie $\mathrm{GmbH}$, Hamburg, Germany, S. Eggerstedt Employee of Bode Chemie GmbH, Hamburg, Germany, N. Nowak Employee of Bode Chemie GmbH, Hamburg, Germany, M. Bashir: None declared.

\footnotetext{
Author details

${ }^{1}$ Bode Science Center, Bode Chemie GmbH, Hamburg, Germany. ${ }^{2}$ Institute for Hygiene and Environmental Medicine, Ernst-Moritz-Arndt University, Greifswald, Germany. ${ }^{3}$ Development, Bode Chemie GmbH, Hamburg,
} 
Published: 20 June 2013

doi:10.1186/2047-2994-2-S1-07

Cite this article as: Kampf et al:: 0007: Lesser and lesser - the impact of small volumes in hand disinfection on quality of hand coverage and antimicrobial efficacy. Antimicrobial Resistance and Infection Control 20132 (Suppl 1):O7.

Submit your next manuscript to BioMed Central and take full advantage of:

- Convenient online submission

- Thorough peer review

- No space constraints or color figure charges

- Immediate publication on acceptance

- Inclusion in PubMed, CAS, Scopus and Google Scholar

- Research which is freely available for redistribution 